\title{
Egg production in China
}

\section{by Yang, Z., Rose, S.P., Yang, H.M. and Pirgozliev, V.}

Copyright, Publisher and Additional Information: This is the author accepted manuscript. The final published version (version of record) is available online via Cambridge University Press

Please refer to any applicable terms of use of the publisher.

DOI: https://doi.org/10.1017/S0043933918000429

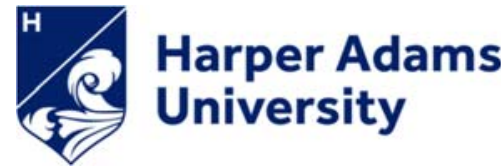

Yang, Z., Rose, S.P., Yang, H.M. and Pirgozliev, V. 2018. Egg production in China. World's Poultry Science Journal. 


\section{Abstract}

4 China has been the world's largest producer of eggs for the last 30 years. There have been

5 considerable recent changes in the structure of the egg industry due to rapid economic growth,

6 improved supply chains and favorable prices. The objective of this report is to examine the

7 changes in the egg industry in China with a special focus on the methods used by poultry

8 producers for egg production within the country.

9 Egg production in China continues to provide the population with a high proportion of their intake of high quality dietary protein. Egg consumption will continue to increase with the rise in the urban population. It is probable that the major increase in demand for eggs will be for out of home consumption and their use in processed food products. Higher levels of production are associated with the spread of intensive systems. The poultry sector is no longer dominated by hundreds of millions of smallholders keeping birds as a sideline activity and many small farmers have ceased production. It is expected that the intensification process will continue to increase. Chinese consumers are becoming more focused on the quality and safety of eggs. Therefore the future developments in the egg production may concentrate on egg quality, safety and traceability of eggs.

Keywords: egg production; laying hen; China 


\section{Introduction}

China produces more than $40 \%$ of all the eggs in the world and its annual production keeps increasing. China is the largest egg producer in the world (Aho, 2002; Magdelaine, 2011). Rapid economic growth, improved supply chains and favourable prices have led to a constant rise in egg consumption. Improving the national food security is a major long-term strategy of the Government and so it has encouraged the development of the laying hen industry within the country (Iddamalgoda et al., 2001; Windhorst, 2006). China has a 5000 year history of egg production but, for almost all of this time, this has been achieved by small-scale backyard family units. However, since the 1980s there has been a rapid expansion of the egg production within the country. Early expansion of the egg industry was led by state-run farms, but the private farming sector now dominates this area of poultry production (Yang, 2000). The numbers of large-scale, vertically-integrated, intensive egg production units have increased significantly at the start of the $21^{\text {st }}$ century. However, smaller husbandry systems that are owned and operated by individual farmers continue to represent a significant part of the overall egg output in the country and still play a key role in a large number of people's livelihoods (Yang, 2011).

China is self-sufficient in egg production although a significant proportion of feed ingredients needed for this production is imported. Outbreaks of high pathogenic H5N1 avian influenza virus in China since 2004 have caused serious concern to the laying hen industry and the Chinese Government (Martin et al., 2011). The Government has taken measures to improve biosecurity in the nation by, when necessary, prohibiting all live bird markets in the cities and closing many small egg production farms (Tan et al., 2013). These regulations have hastened 
change in the Chinese egg production industry in the early years of the $21^{\text {st }}$ century.

Egg production in China continues to be the largest in the world but there have been considerable recent changes in the structure of the industry. It is important to not only understand the structure of the current Chinese egg industry but also to understand the changing demand for eggs in the Chinese egg market. The objective of this review is to examine the recent changes in the egg industry in China. A further objective is to understand how the industry manages to supply their eggs to the areas of demand and also to explain the methods used by poultry farmers for egg production within China.

\section{Production and demand for eggs in China}

Egg production in China has continued to increase in each of the years since 2000. The average annual growth rate of egg production was approximately 0.6 million tonnes per year from 2000 to 2016 (FAO, 2017). In 2016, the total eggs produced in China reached a peak of 31 million tonnes. All of the increase in hen egg consumption in China has been achieved by increasing the amount of domestic production. China is self-sufficient in shell egg production and has a very small number of imported eggs that is offset by a larger, but still relatively small, net export of eggs (FAO, 2017): In 2013, the quantities of imported and exported eggs were 175 and 100 000 tonnes, respectively. More than $70 \%$ of imported eggs are hatching eggs destined for use as breeding stock. The majority of exported shell eggs are sent to Hong Kong (90\%) and Macau (10\%). Exported eggs account for only $0.5 \%$ of the annual domestic production (USDA, 2014). The egg consumption of the Chinese population has continued to increase in recent years. Eggs contribute approximately $6 \%$ of the protein supply in the diets of Chinese citizens. This proportion has increased slowly in recent years, although not at the same rate of increase that 
has occurred for pig and poultry meat (Figure 1). Meanwhile, the contribution of protein from cereals has markedly decreased. Urban residents eat approximately $70 \%$ more eggs than rural residents but this difference is rapidly changing; The greatest increases in egg consumption have been in the population living in rural areas, whereas egg consumption in the urban population has remained approximately stable (Figure 2). Egg consumption in rural families is still much lower than that in urban families $(5.9 \mathrm{~kg}$ eggs per capita vs. $10.5 \mathrm{~kg}$ eggs per capita in 2012), but with the rapid increase in urbanization it is expected that the future demand for eggs will continue to increase (Wang et al., 2015). In 2010, home consumption of eggs accounted for $53 \%$ of egg sales with out of home consumption accounting for $28 \%$ and $19 \%$ further processed egg (Figure 3). Home consumption of shell eggs increased slowly whereas further processed egg consumption more than doubled (144\% increase) between 2000 and 2010, and out of home consumption rose by approximately $40 \%$ during this time.

In the five years since 2012 , the annual revenue for the poultry industry has grown at an average rate of $8.7 \%$ per annum (NBSC, 2017). Eggs are mostly sold by the farmers to wholesalers. The proportion of eggs sold through supermarkets is increasing, although not at the rate of the wholesale market for eggs. There is an increasing number of small shops or street stalls that sell poultry products and this remains the dominant route for egg sales in the country. The retail egg price is approximately $30-40 \%$ greater than the price received by the egg producers. Urban families with high incomes are becoming increasingly concerned about their long-term health and the state of the environment and some are prepared to buy organic or freerange eggs. Speciality eggs are emerging in response to the demand from these affluent urban consumers (Zhang et al., 2016; Godfray et al., 2010). Approximately five percent of eggs are 
branded and this yields a 2 to 5 -fold premium in margin over the generic product (Ke and Han, 2007).

Egg price has relatively little effect on consumer demand for eggs: The egg market in China is relatively price inelastic and this is particularly the case in urban residents and most profound in those in high income brackets (Table 1) (Ke and Han, 2007). Demand for eggs is more price elastic in rural communities but this is also less evident in high income households with high protein intakes. Low income households have relatively low protein intakes (Popkin and $\mathrm{Du}, 2003$ ), and at times of high animal protein prices, they would change to buy cheaper alternative foods such as pulses and a higher proportion of grains. The farm price of eggs is therefore highly sensitive to changes in production levels and the supply of eggs. There are seasonal fluctuations in egg price with the lowest prices occurring in late spring and the highest in the autumn (CAAA, 2017) (Li et al., 2010). As discussed in the next section, there is a significant proportion of egg production systems that do not use fully environment-controlled buildings. These systems most probably have large seasonal changes in their egg production from spring to autumn and so have a significant effect on the numbers of eggs that enter the wholesale market at these times. A three year cycle in egg prices is also evident in the Chinese market (Figure 4). Relatively small egg producers tend to have low-cost poultry houses and so have low fixed capital costs for their egg production enterprise. These producers may delay restocking their houses at times of low egg prices and so this results in this cycle of changing egg prices (Gueye, 2009; Zhou and Li, 2012). The decision to Table 1 Income elasticity estimates for eggs for urban and rural households in China, 2005 (Ke and Han, 2007). 


\begin{tabular}{|c|c|c|c|c|c|c|c|}
\hline \multirow{2}{*}{ Income group } & lowest & low & $\begin{array}{l}\text { Lower } \\
\text { middle }\end{array}$ & Middle & $\begin{array}{l}\text { Upper } \\
\text { middle }\end{array}$ & High & Highest \\
\hline & $10 \%$ & $10 \%$ & $20 \%$ & $20 \%$ & $20 \%$ & $10 \%$ & $10 \%$ \\
\hline $\begin{array}{c}\text { Egg } \\
\text { consumption }(\mathrm{kg})\end{array}$ & 8.3 & 10.2 & 11 & 11.6 & \multicolumn{2}{|l|}{11.9} & 11.5 \\
\hline Elasticity for eggs & - & 0.469 & 0.158 & 0.167 & 0.081 & 0.213 & -2.027 \\
\hline \multicolumn{8}{|l|}{ Rural households } \\
\hline \multirow{2}{*}{ Income group } & low & & Lower middle & Middle & \multicolumn{2}{|c|}{ Upper middle } & High \\
\hline & $20 \%$ & & $20 \%$ & $20 \%$ & \multicolumn{2}{|c|}{$20 \%$} & $20 \%$ \\
\hline $\begin{array}{c}\text { Egg } \\
\text { consumption } \\
(\mathrm{kg})\end{array}$ & 2.6 & & 3.7 & 4.6 & \multicolumn{2}{|c|}{5.6} & 7.3 \\
\hline $\begin{array}{c}\text { Elasticity for } \\
\text { eggs }\end{array}$ & - & & 0.852 & 0.389 & \multicolumn{2}{|c|}{0.372} & 0.609 \\
\hline
\end{tabular}

112 restock may also be affected by changes in the costs of production. In the last decade, egg

113 production costs at farm level have generally changed with the change in layer feed prices. Both

114 the production cost and the feed price reached a peak in 2013. Average cost of the egg

115 production was 8.7 Yuan $/ \mathrm{kg}(\$ 1.31 / \mathrm{kg})$ and the average feed price was 2350 Yuan/ tonne (\$352

116 /tonne) (IEC, 2016). Variation in feed costs remain the major, but not the only, influence on

117 production costs.

118 In conclusion, the egg production continues to provide the population with a high 
proportion of their intake of high quality dietary protein. Egg consumption will continue to increase with the rise in the urban population. It is probable that the major increase in demand for eggs will be for out of home consumption and their use in further-processed food products.

\section{Structure of industry}

Egg production in China has grown steadily over recent years and there was a $24 \%$ increase in production in the ten years from 2006 to 2015. Eggs are produced in all provinces of China but now production is concentrating in a relatively few provinces (Figure 5). Ten Chinese provinces produces $80 \%$ of the national eggs. In order to meet the consumer's demands in the whole nation there is a substantial movement of eggs around the country. Eggs are transported from North and Northeast China to Southeast and South China as well as into big cities like Beijing, Tianjin and Shanghai. The province of Guangdong, in the south of China, has the largest gap between supply and demand with an inflow of 2 million tonnes each year, followed by Shanghai (0.75 million tonnes), Zhejiang ( 0.7 million tonnes) and Beijing ( 0.6 million tonnes) (Table 2). The concentration of egg production in the North and North-East of China is probably mostly due to the availability of locally produced cereals as well as good access to ports for imported feedstuffs. Recent major improvements in the transport infrastructure by the Chinese Government have facilitated this centralization in the egg production industry (Démurger, 2001).

Table 2 Net egg flows (million tonnes/ year) and resident population (year-end) (10 000 residents) of each province in China in 2015 (Adapted from China Animal Agriculture Association, 2017 and National Bureau of Statistics of China, 2017). 


\begin{tabular}{|c|c|c|}
\hline Province & $\begin{array}{c}\text { Egg flows (million } \\
\text { tonnes/ year) }\end{array}$ & The population (million) \\
\hline Hebei & 1.8 & 74.3 \\
\hline Henan & 1.7 & 94.8 \\
\hline Liaoning & 1.5 & 43.8 \\
\hline Shandong & 1.0 & 98.5 \\
\hline Jilin & 0.5 & 27.5 \\
\hline Hubei & 0.4 & 58.5 \\
\hline Heilongjiang & 0.4 & 38.1 \\
\hline Sichuan & 0.3 & 82.0 \\
\hline Inner Mongolia & 0.3 & 25.1 \\
\hline Shaanxi & 0.1 & 37.9 \\
\hline Ningxia & 0.1 & 6.7 \\
\hline Xinjiang & 0.1 & 23.6 \\
\hline Tibet & 0.1 & 3.2 \\
\hline Hunan & 0.1 & 67.8 \\
\hline Qinghai & 0.1 & 5.9 \\
\hline Hainan & 0.1 & 9.1 \\
\hline Shanxi & 0.1 & 45.7 \\
\hline Jiangsu & 0.1 & 79.8 \\
\hline Gansu & -0.08 & 26.0 \\
\hline Guizhou & -0.1 & 35.3 \\
\hline Anhui & -0.15 & 61.4 \\
\hline Yunnan & -0.2 & 47.4 \\
\hline Chongqing & -0.23 & 30.2 \\
\hline Guangxi & -0.25 & 48.0 \\
\hline Jiangxi & -0.3 & 45.7 \\
\hline Tianjin & -0.4 & 15.5 \\
\hline Fujian & -0.55 & 38.4 \\
\hline \multirow[t]{2}{*}{ Beijing } & -0.6 & 21.7 \\
\hline & 8 & \\
\hline
\end{tabular}




\begin{tabular}{lcc} 
Zhejiang & -0.7 & 55.4 \\
Shanghai & -0.75 & 24.2 \\
Guangdong & -2.0 & 108.5 \\
\hline
\end{tabular}

141

142

*Positive number represents the quantity of the exported eggs to other provinces; Negative number represents the quantity of the imported eggs to the province.

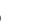

Henan, Shangdong, Hebei, Liaoning, Sichuan and Jiangsu, the six largest egg-producing provinces, accounted for nearly $61 \%$ of the total production of the country (NBSC, 2017). Most of these provinces have increased their egg production in recent years, except for Hebei. The reduction in egg production in Hebei may be due to the relatively large number of small egg producers in this province that may be ceasing production due to Government legislation, the poorer viability of relatively small-scale production methods and the availability to them of other employment opportunities in the nearby, rapidly developing, urban areas (Li et al., 2010). Intensification of egg production has occurred throughout the country. In 2008, $43 \%$ of all eggs produced were from flocks with sizes less than 2000 hens, but in 2014 this size of egg producer only supplied $4 \%$ of the total eggs produced in China (Table 3). Large numbers of relatively small independent egg producers still exist and, in 2014, over 50\% of all eggs produced were from flock sizes of less than 10000 hens. However, large integrated companies have also been established and many of these manage large operations. The top six largest egg producers (Beijing Huadu Yukou Poultry Company, Beijing Pinggu Charoen Pokphand, Beijing Deqingyuan Poultry Company, Anhui Rong Da and Shanxi Dajiang Nongke ) have flock sizes of more than 5 million laying hens. Such companies are mostly vertically integrated and manage the bird husbandry, feed milling, transport and distribution of the eggs. The recent increases in 
167

the average size of Chinese egg production units are similar to the way which the egg production industries of developed countries, such as European Union and United States, changed in previous years (Mench et al., 2011).

Table 3 Size of laying hen units and their contribution to the proportion of total eggs produced in China in 2008 and 2014 (Adapted from China Animal Agriculture Association, 2016)

\begin{tabular}{ccc}
\hline $\begin{array}{c}\text { Size of production unit } \\
\text { (Number of hens) }\end{array}$ & $\begin{array}{c}\text { Contribution to total egg } \\
\text { production in 2008 }(\%)\end{array}$ & $\begin{array}{c}\text { Contribution to total egg } \\
\text { production in } 2014(\%)\end{array}$ \\
\hline 2000 & 43.6 & 3.5 \\
$2000 \sim 4999$ & 16.0 & 27.5 \\
$5000 \sim 9000$ & 18.0 & 25.9 \\
$10000 \sim 50000$ & 17.0 & 34.9 \\
$50000 \sim 100000$ & 2.9 & 5.7 \\
$100000 \sim 500000$ & 2.5 & 2.5 \\
\hline
\end{tabular}

\section{Management methods}

Eggs are primarily produced in cage systems regardless of the size of the enterprise. Ninety percent of eggs are produced from cage systems with $9 \%$ in free-range systems and $1 \%$ in barn systems (IEC, 2016). Large, modern egg production farms increasingly use environmentcontrolled buildings in which cages incorporate automatic feed delivery and automatic egg collection equipment (Table 4). Recently built egg production farms are typically on sites with up to half a million hens. There are only a few sites that have more than a million birds. Small egg production farms (less than 10000 hens) typically use houses, such as polythene 
tunnels, old greenhouses, or other farm buildings, that have little, or poor, environmental control.

The tiered cages that are installed in these buildings often have little automation and so feed is delivered by hand and eggs are collected manually (Table 4). This type of production requires a high labour input and this is mostly provided by farmers who are keeping birds as a sideline activity. However less people now like to work in the rural countryside an there are better employment opportunities in urban areas. Many small farmers have given up production.

There has been growth in the free-range and organic chicken production segments over the past five years, but these account for a very small number of chickens farmed. However this is slowly shifting as Chinese consumers are now increasingly willing to buy cage-free eggs (Wang et al., 2017; Rakonjac et al., 2014; Zhang et al., 2016).

Laying hen strains that produce brown shelled eggs are the predominant stock used in the Chinese industry. Approximately $70 \%$ of eggs sold are brown shelled (IEC, 2017). Hyline supplies $77 \%$ of all the laying stock (brown shelled eggs) whereas a Chinese breeding company, Jinghong and Jingfen, supply $12 \%$ of the birds (tinted brown shells) (NBSC, 2017). The remaining $11 \%$ of laying stock are supplied by Lohmann (brown shelled eggs), Nongda (white shelled eggs) and there are some traditional breeding companies that produce stock that lay green shelled eggs. 


\begin{tabular}{|c|c|c|c|c|c|c|c|}
\hline \multirow[b]{2}{*}{ Number of hens/ farm } & \multirow{2}{*}{$\begin{array}{l}\text { Percent in } \\
\text { tiered cages }\end{array}$} & \multicolumn{2}{|c|}{ Drinker type } & \multicolumn{2}{|c|}{ Feeding type } & \multicolumn{2}{|c|}{ Egg collection } \\
\hline & & $\begin{array}{l}\text { Water } \\
\text { trough }\end{array}$ & $\begin{array}{l}\text { Nipple or cup } \\
\text { drinker }\end{array}$ & Manual feeding & Automated feeding & Manual egg & Automated egg \\
\hline$<2000$ & 92.5 & 22.2 & 77.8 & 98.5 & 1.5 & 99.5 & 0.5 \\
\hline $2000 \sim 4999$ & 87.2 & 15.1 & 84.9 & 96.9 & 3.1 & 99.7 & 0.3 \\
\hline $5000 \sim 9000$ & 87.7 & 11.1 & 88.9 & 88.9 & 11.1 & 99.4 & 0.6 \\
\hline $10000 \sim 50000$ & 92.9 & 8.6 & 91.4 & 61.6 & 38.4 & 96.1 & 3.9 \\
\hline $50000 \sim 100000$ & 91.4 & 2.3 & 97.7 & 31.8 & 68.2 & 88.1 & 11.9 \\
\hline $100000 \sim 500000$ & 95.2 & 10.0 & 90.0 & 15.1 & 84.9 & 77.8 & 22.2 \\
\hline
\end{tabular}


to stock to the economic optimum. Most large integrated companies keep flocks for a 60 to 70 weeks laying period whereas small independent producers may use extended laying periods depending on the market conditions that prevail.

\section{Conclusions}

200 Egg production continues to provide the population with a high proportion of their intake of high quality dietary protein. Egg consumption will continue to increase with the rise in the urban population. It is probable that the major increase in demand for eggs will be for out of home consumption and their use in further-processed food products. The poultry sector is no longer dominated by hundreds of millions of smallholders keeping birds as a sideline activity. continue. Small-scale and non-commercial farmers will continue their exit from the industry.

It is possible that the number of poultry farmers in China could halve by 2020 . The egg production is concentrated in some regions of China and there is a logistical network evolving that distributes the eggs to the consumer. Chinese consumers are becoming more focused on the quality and safety of eggs. Therefore the future developments in the egg production market 212 may concentrate on egg quality, safety and traceability of eggs.

\section{Acknowledgments}

214 This review was produced as part of the Project of Jiangsu Province Policy Leading Program 215 of the People's Republic of China (SZ-HA2017010) and the Scientific Research Foundation 
216 of PhD Student of Yangzhou University.

217 References

218 AHO, P. W. (2002) The World's commercial chicken meat and egg industries. In: Bell D.D., 219 Weaver W.D. (eds) Commercial Chicken Meat and Egg Production. pp. 3-17 (US, Springer).

220 CAAA (2017) China Animal Agriculture Association. http://www.caaa.cn/ (Accessed $22115 / 11 / 2017)$

DEMURGER, S. (2001) Infrastructure development and economic growth: an explanation for regional disparities in China. Journal of Comparative Economics, 29: 95-117.

FAO (2017) FAO Country star. http://www.fao.org/faostat/en/\#data/TP (Accessed 15/11/2017).

IDDAMALGODA, A., HAYASHI, S., GOTO, E., SUGIYAMA, M. and OGURI, K. (2001)

226 Current Asian trends in egg production and consumption: a demand analysis of selected countries. World's Poultry Science Journal 57: 49-54.

IEC (2017) International Egg commission https://www.internationalegg.com/ (Accessed $15 / 11 / 2017)$.

GODFRAY, H. C. J., BEDDINGTON, J. R., CRUTE, I. R., HADDAD, L., LAWRENCE,

Food security: the challenge of feeding 9 billion people. Science 327: 812-818.

GUEYE, E. F. (2009) The role of networks in information dissemination to family poultry farmers. World's Poultry Science Journal 65: 115-124.

KE, B. and HAN, Y. (2007) Poultry sector in China: structural changes during the past decade 236 and future trends. In poultry in the 21 st century: avian influenza and beyond. Proceedings of 
the International Poultry Conference, Bangkok. pp. 1-33.

LI, Z. M., XU, S. W., DONG, X. X., LI, G. Q., LIU, H. and WANG, Y. T. (2010) The shortterm market price transmission mechanism of egg industry chain in China. Scientia Agricultura Sinica 43: 4951-4962.

MAGDELAINE, P. (2011) Egg and egg product production and consumption in Europe and the rest of the world. In: Improving the safety and quality of eggs and egg products: Egg chemistry, production and consumption, Vol. 1, pp. 3-16 (UK, Woodhead Publishing).

MARTIN, V., PFEIFFER, D. U., ZHOU, X., XIAO, X., PROSSER, D. J., GUO, F. and GILBERT, M. (2011) Spatial distribution and risk factors of highly pathogenic avian influenza (HPAI) H5N1 in China. PLoS pathogens 7: 1-11.

MENCH, J. A., SUMNER, D. A. and ROSEN-MOLINA, J. T. (2011) Sustainability of egg production in the United States-The policy and market context. Poultry Science, 90: 229-240. NBSC (2017) National Bureau of Statistics of China. http://data.stats.gov.cn/index.htm (Accessed 16/11/ 17).

POPKIN, B. M. and Du, S. (2003) Dynamics of the nutrition transition toward the animal foods sector in China and its implications: a worried perspective. The Journal of Nutrition, 133: 3898S-3906S.

RAKONJAC, S., BOGOSAVLJEVIĆ-BOŠKOVIĆ, S., PAVLOVSKI, Z., ŠKRBIĆ, Z., DOSKOVIĆ, V., PETROVIĆ, M. D. and PETRIČEVIĆ, V. (2014) Laying hen rearing systems: A review of major production results and egg quality traits. World's Poultry Science Journal 70: 93-104. 
258

259

260

261

262

263

264

265

266

267

268

269

270

271

272

273

274

275

276

277

278

TAN, Z., SHEN, Y. and YANG, D. (2013) The effect and influence of closing live poultry markets to control and prevent human avian influenza infection. Chinese Journal of Health Policy 6: 67-85.

USDA (2014) International egg and poultry review. United State Department of Agriculture. https://www.usda.gov/ (Accessed 16/11/ 17).

WANG, J., CHEN, J. and LIU., H. (2015) China's egg consumption and its influencing factors. Agricultural Outlook 1: 75-80.

WANG, J., YUE, H., WU, S., ZHANG, H. and QI, G. (2017) Nutritional modulation of health, egg quality and environmental pollution of the layers. Animal Nutrition 3: 91-96.

WINDHORST, H. W. (2006) Changes in poultry production and trade worldwide. World's Poultry Science Journal 62: 585-602.

YANG, N. (2000) Review and prospect of Chinese egg industry on the eve of the new century. China Poultry 22: 1-3.

YANG, N., QIN, F., XU, G., ZHAO, Y., XUE, L. and ZHOU, X. (2014) Analysis of current status of Chinese egg industry in 2013. China Poultry 36: 2-9.

YANG, N. (2011) Social economic aspects of egg production in China. In: Improving the safety and quality of eggs and egg products: Egg chemistry, production and consumption, Vol. 2, pp. 17-26 (UK, Woodhead Publishing).

ZHANG, G., CHEN, A., ZHAO, Y., XU, Z., CHEN, G. and YANG, S. (2016) Egg safety standards in China need to be improved. Journal of Food Protection 79: 512-515.

ZHOU, H. and LI, H. (2012) Fluctuation analysis of the price of eggs in the $21^{\text {st }}$ century. 
279 Journal of Beijing University of Agriculture 27: 49-52.

280

281 
Figure 1 The contribution of different human foods to the total protein supply in China (Adapted from FAO, 2017).

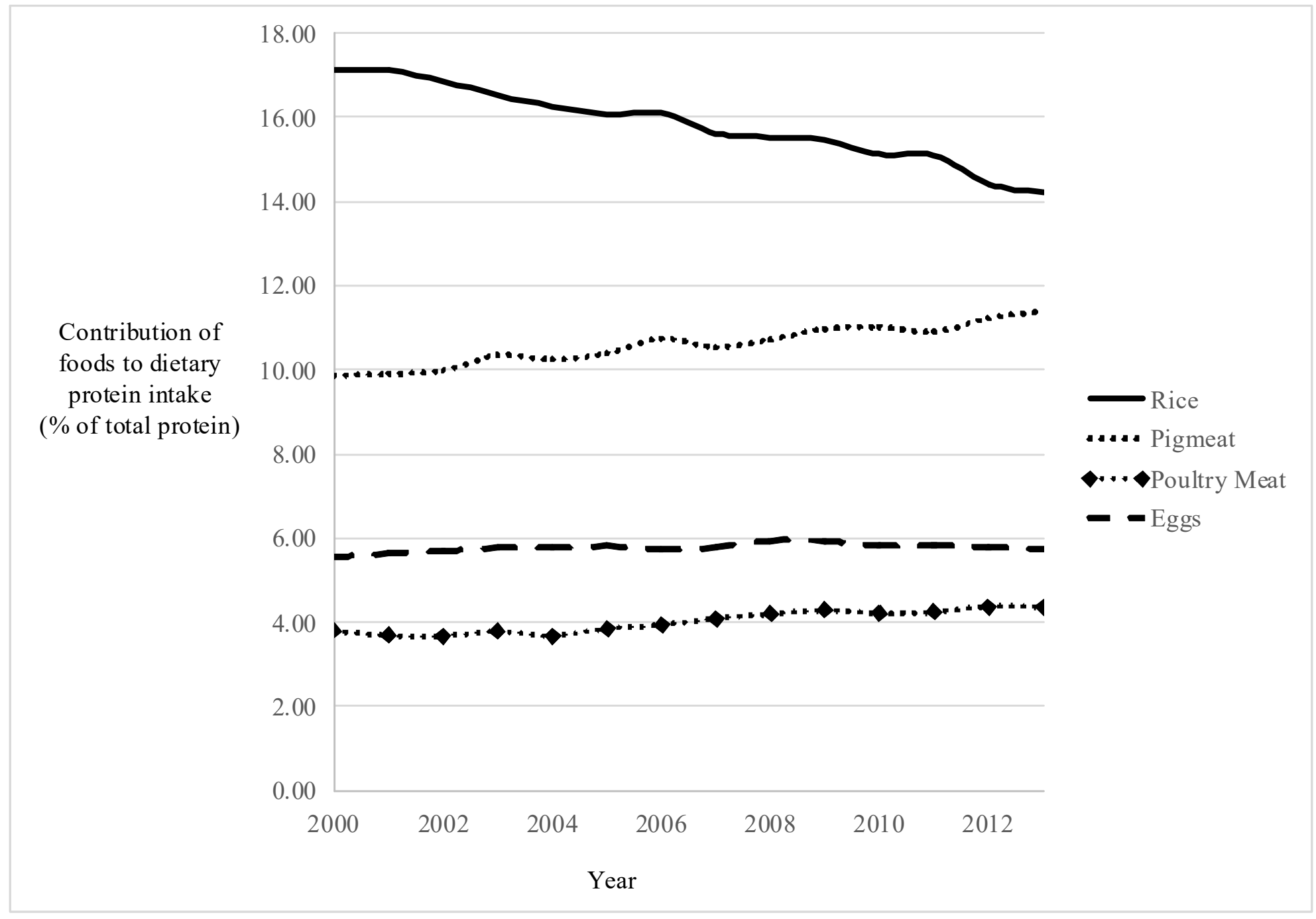


Figure 2 Egg consumption of urban and rural people in China (Adapted from National Bureau of Statistics of China, 2017).

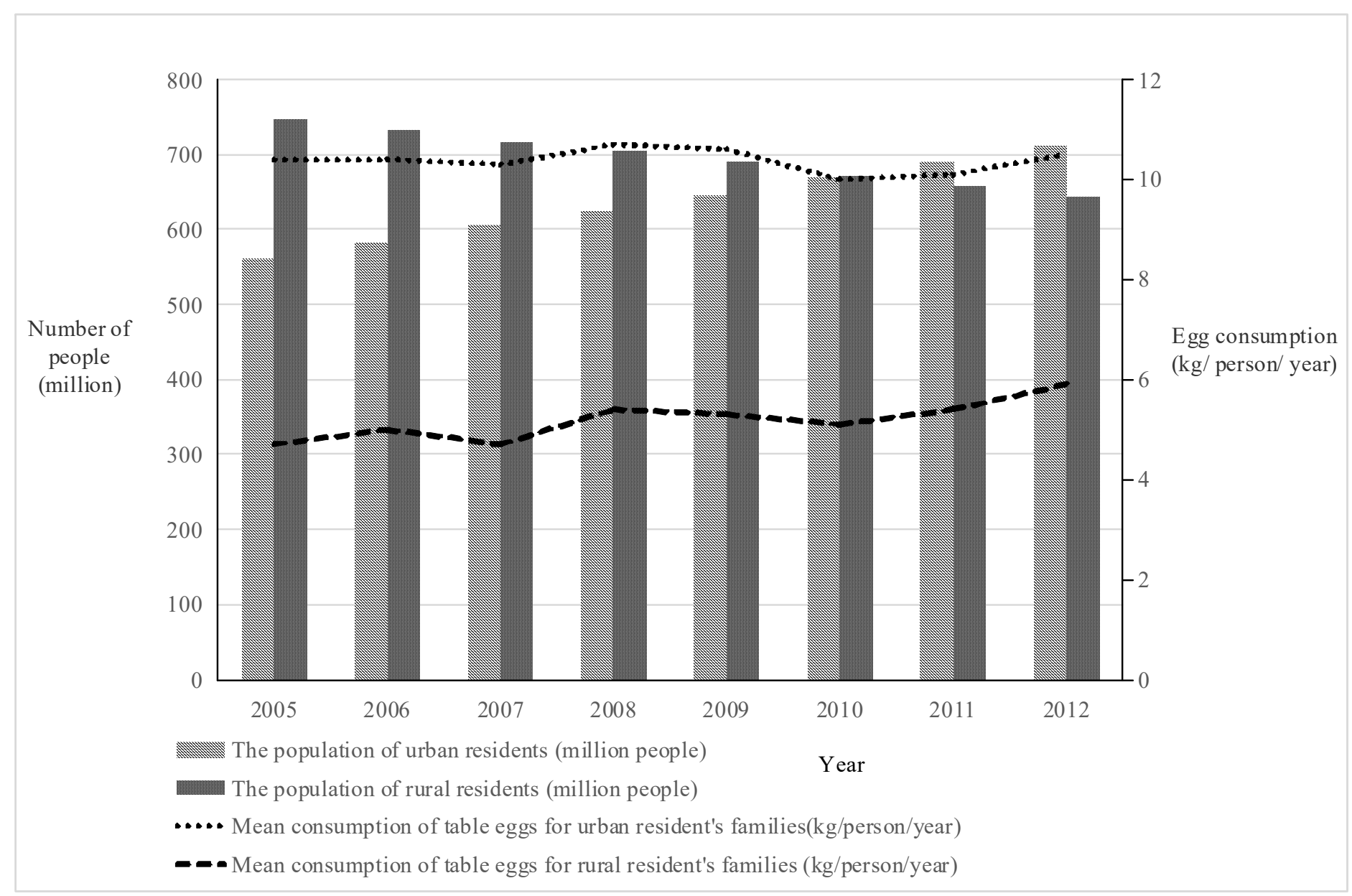


Figure 3 Egg consumption in China from 2000 to 2010 (Adapted from National Bureau of Statistics of China, 2017).

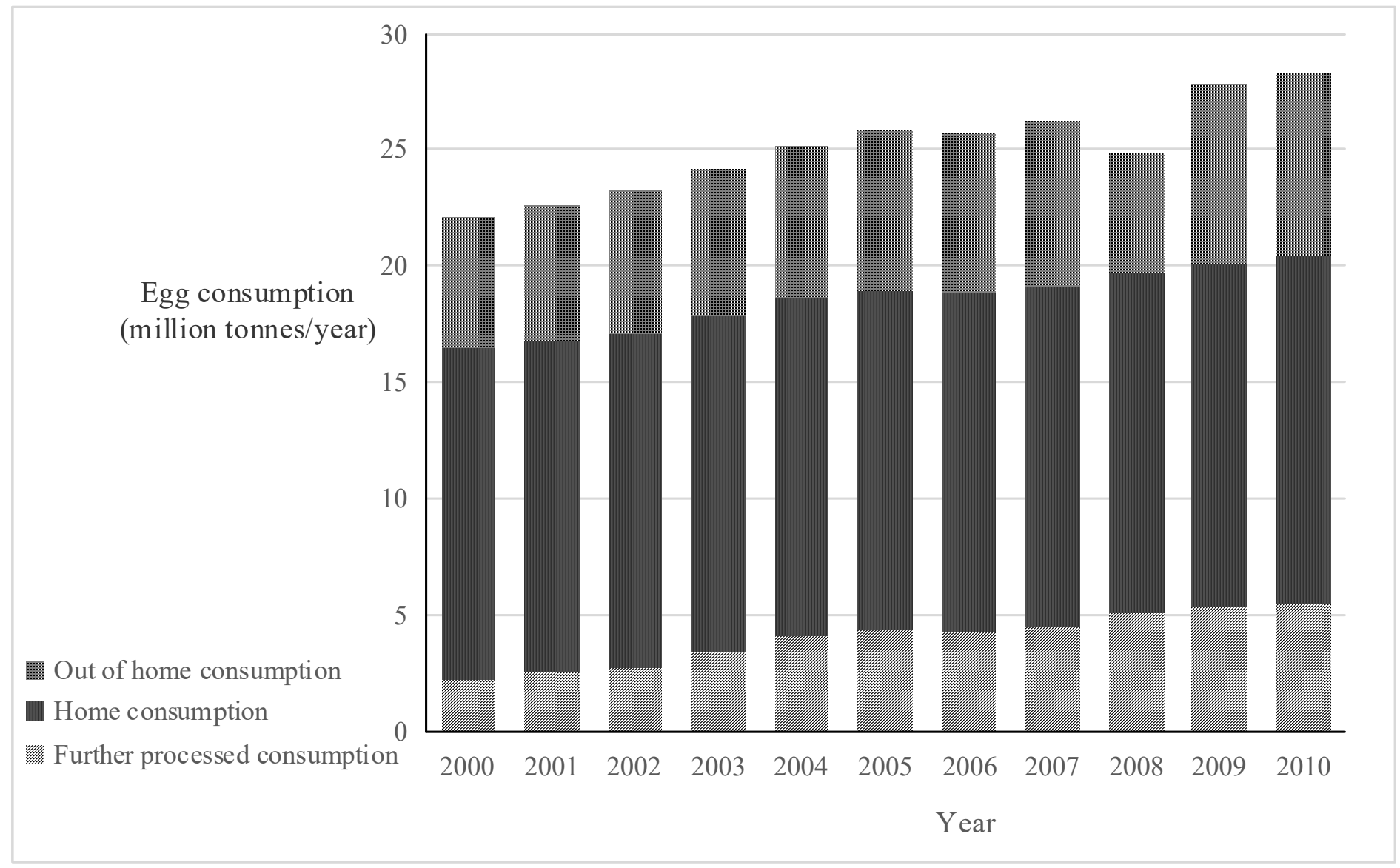


Figure 4 Annual trend of egg price in China from 1997 to 2013 (Yuan $1 / \mathrm{kg}$ ) (Adapted from China Animal Agriculture Association, 2017).

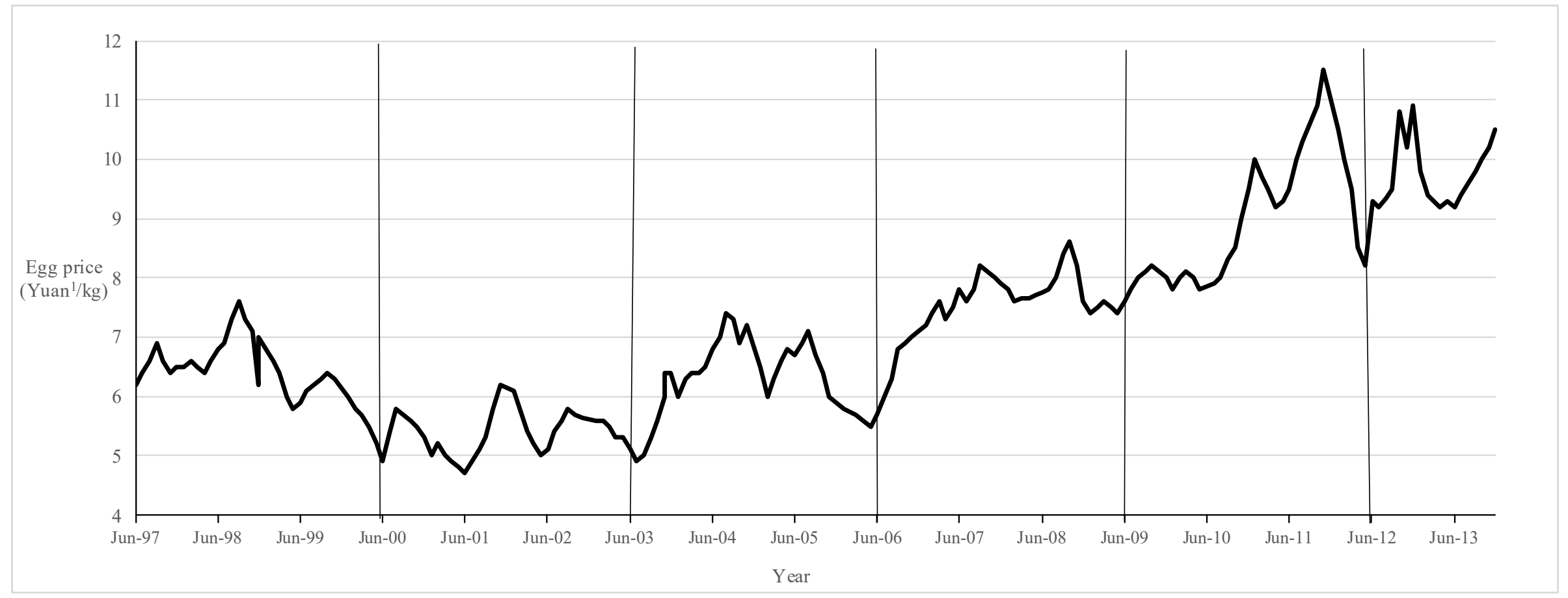

${ }^{1}$ Currency conversion used: One Chinese Yuan $=0.15$ US\$

${ }^{2}$ Vertical lines indicate the duration of egg price cycle. 
Figure 5 The output of poultry eggs (million tonnes per year) and the resident population (year-end) of China in 2015 (Adapted from National Bureau of Statistics of China, 2017).
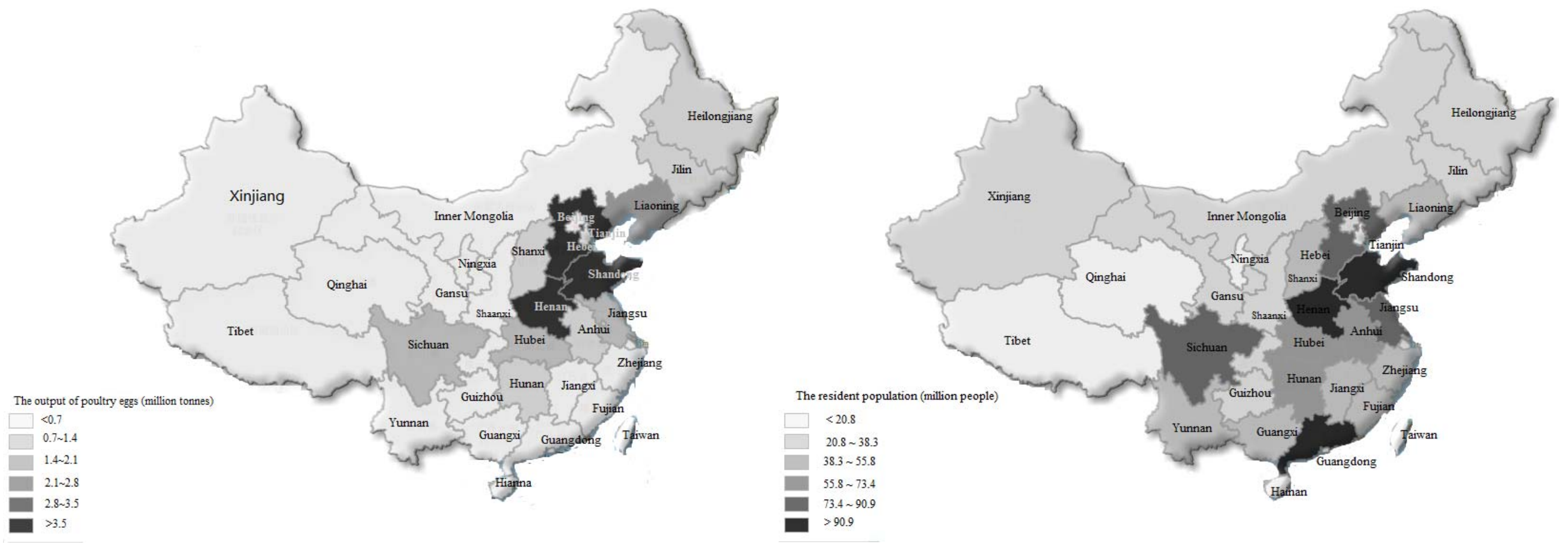